\title{
Hymn o Bogu Stwórcy (Rdz 1,1-2,4a) w interpretacji Księgi Jubileuszów (Jub 2)
}

\section{Hymn to the Creator (Gen 1,1-2,4a) in the interpretation of the Book of Jubilees (Jub 2)}

Słowa kluczowe: Księga Rodzaju, historia stworzenia, Bóg - Stworzycie, Księga Jubileuszy, interpretacja historii stworzenia, stworzenie aniołów, wybranie Izraela, szabat.

Keywords: Genesis, creation story, God the Creator, Jubilees, interpretation of the creation story, creation of the angels, Israel's election, the sabbath.

Dismo noszące tytuł Księga Jubileuszów (lub Mała Księga Rodzaju) przedstawia się jako objawienie dane Mojżeszowi na górze Synaj za pośrednictwem anioła obecności (Jub 1,27.29; 2,1). Stanowi ono parafrazę Rdz i Wj 1-12 i jest przepracowaniem tekstu biblijnego przez wzbogacenie go licznymi nowymi elementami, a niekiedy pomijaniem tych zagadnień, które nie odpowiadały koncepcji teologicznej jej autora (ang. rewritten Bible). Treścią księgi jest opis historii od stworzenia świata do nadania Izraelowi Prawa na Synaju, która została ujęta w ramy kolejnych jubileuszów, tj. 49 lat każdy. Autor uwypukla wybranie Izraela, gloryfikuje Prawo i akcentuje tradycje kapłańskie, między innymi kalendarz słoneczny, wiodącą rolę Lewiego jako nauczyciela Prawa, szczegółowe sprawy dotyczące kultu ${ }^{1}$.

1 Na temat ogólnych informacji dotyczącej tej księgi, zob. R. Rubinkiewicz, Wprowadzenie do apokryfów Starego Testamentu, Lublin 1987, 89-92; S. Mędala, Wprowadzenie do literatury międzytestamentalnej (BZ.TNT 1), Kraków 1994, 239-240; E. Schürer, The History of the Jewish People in the Age of Jesus Christ (175 B.C.-A.D. 135), t. III/1, Edinburgh 1995, 308-318; J. C. VanderKam, The Book of Jubilees (Guides to Apocrypha and Pseudepigrapha), Sheffield 2001; H. Najman, Seconding Sinai. The Development of Mosaic Discourse in Second Temple Judaism (JSJSup 77), Leiden 2003, 41-69; G.W. E. Nickelsburg, Jubilees, w: M.E. Stone (red.), Jewish Writings of the Second Temple Judaism (CRINT II/2), Assen - Philadelphia 
Większość uczonych zgadza się z opinią, że Księga Jubileuszów powstała w Palestynie w połowie II w. przed Chr. (najprawdopodobniej w latach 170-140), ale na temat ustalenia dokładniejszej daty istnieją różne hipotezy². Pismo na pewno istniało już pod koniec II w. przed Chr., o czym świadczy najwcześniejszy rękopis Księgi Jubileuszów odnaleziony w Qumran (4Q216), który na podstawie badań paleograficznnych jest datowany na lata 125-100 przed Chr., lub nieco wcześniej3. Chociaż trudno jednoznacznie określić środowisko powstania Księgi Jubileuszów, to wiele wskazuje na jej kapłańską proweniencję. Warto też zauważyć, że wykazuje ona wiele zbieżności z pismami qumrańskimi oraz z tradycją henochiczną, mianowicie z Ksiegga astronomiczna (1 Hen 72-82), Apokalipsa zwierząt (1 Hen 85-90) i Apokalipsa tygodni (1 Hen 93,1-10; $91,11-17)^{4}$.

Dzieło zostało napisane $\mathrm{w}$ języku hebrajskim, a następnie przetłumaczone na język grecki i syryjski. Z greckiego księgę przetłumaczono na język etiopski i łaciński. W całości tekst Księgi Jubileuszów zachował się jedynie w wersji etiopskiej, poza tym istnieją fragmenty wersji łacińskiej i syryjskiej. Wersja grecka jest znana z cytatów patrystycznych ${ }^{5}$. Na szczególną uwagę zasługują fragmenty rękopisów Księgi Jubileuszów z Qumran, a mianowicie 1Q17-18; 2Q19-20; 3Q5; 4Q176; 4Q216-222; 4Q223-224; 11Q12. Dokładna liczba kopii tej księgi nie jest

1984, 97-104; tenże, Jewish Literature between the Bible and the Mishnah. A Historical and Literary Introduction, Minneapolis 2005, 69-74; M. Segal, The Book of Jubilees: Rewritten Bible, Redaction, Ideology and Theology (JSJSup 117), Leiden 2007, 1-41; S. W. Crawford, Rewriting Scripture in Second Temple Times (SDSSRL), Grand Rapids-Cambridge 2008, 60-83.

2 Omówienie różnych opinii na temat datacji, zob. J. C. VanderKam, Textual and Historical Studies in the Book of Jubilees (HSM 14), Missoula 1977, 207-285; tenże, The Book of Jubilees (Guides to Apocrypha and Pseudepigrapha), 17-21; G. W. E. Nickelsburg, Jewish Literature between the Bible and the Mishnah, 73-74; M. Segal, The Book of Jubilees, 35-41.

3 Zob. J. C. VanderKam, J. T. Milik, Jubilees, w: H. Attridge, i in. (red.), Qumran Cave 4.VIII: Parabiblical Texts, Part 1 (DJD 13), Oxford 1994, 2.

4 Zob. R. H. Charles, The Book of Jubilees or the Little Genesis, London 1902, 73; K. Berger, Das Buch der Jubiläen, w: JSHRZ II/3, 298; O. S. Wintermute, Jubilees (Second Century B.C.). A New Translation and Introduction, w: OTP II, 45; J. Endres, Biblical Interpretation in the Book of Jubilees (CBQMS 18), Washington 1987, 238-249; J. C. VanderKam, The Origins and Purposes of the Book of Jubilees, w: M. Albani i in. (red.), Studies in the Book of Jubilees (TSAJ 65), Tübingen 1997, 19; G. W. E. Nickelsburg, Jewish Literature between the Bible and the Mishnah, 74; M. Segal, The Book of Jubilees, 10-11.

5 Krytyczne wydanie tekstu etiopskiego oraz fragmentów greckich, syryjskich i łacińskich, jak również częściowo tekstów odnalezionych w Qumran (1Q18; 2Q19-20; 3Q5; 4Q176; 4Q221; 11Q12) opracował J. C. VanderKam, The Book of Jubilees. A Critical Text (CSCO 510; Scriptores Aethiopici 87), t. I, Louvain 1989. 
znana i waha się między liczbą trzynastu a szesnastu manuskryptów. Powodem tego stanu rzeczy jest fakt, że dwie kopie z groty pierwszej mogą należeć do tego samego zwoju, fragmenty z groty trzeciej mogą reprezentować więcej niż jeden rękopis, natomiast identyfikacja 4Q217 nie jest pewna. Kolejnych sześć zwojów jest łączonych z Księga Jubileuszów, a mianowicie cztery z Qumran (4Q225-227; 4Q228) oraz dwa z Masady (Mas 1j; Mas 1i). Wszystkie kopie prezentują tekst w języku hebrajskim, a ich duża liczba świadczy o autorytatywnym charakterze księgi w społeczności qumrańskiej6.

\section{Rdz 1 w interpretacji Jub 2 - ogólne spojrzenie}

Sytuacja tekstualna Jub 2 jest względnie dobra, ponieważ jak zauważa J. C. VanderKam, tekst etiopski może być zweryfikowany dzięki zachowanym fragmentom tekstu hebrajskiego, greckiego i syryjskiego ${ }^{7}$. Znalezione w Qumran rękopisy Księgi Jubileuszów zawierają fragmenty tekstu hebrajskiego z jej drugiego rozdziału, w którym znajduje się opis stworzenia świata: 4Q216 frag. 1, kol. 5 (= Jub 2,1-4), 4Q216 frag. 1, kol. 6 (= Jub 2,7-12), 4Q216 frag. 1, kol. 7 (= Jub 2,13-24), 4Q218 frag. 1 (= Jub 2,26-27) ${ }^{8}$. Grecki tekst, który zachował się u Epifaniusza (De mensuris et ponderibus, 22), odpowiada Jub 2,2-20. Chociaż jest on często skracany w stosunku do tekstu etiopskiego, to jednak w tych

6 Zob. P. W. Flint, Noncanonical Writings in the Dead Sea Scrolls: Apocrypha, Other Previously Known Writings, Pseudepigrapha, w: P. W. Flint (red.), The Bible at Qumran. Text, Shape, and Interpretation (SDSSRL), Grand Rapids-Cambridge 2001, 100-103; J. C. VanderKam, Jubilees, Book of, w: L. H. Schiffman i in. (red.), Encyclopedia of the Dead Sea Scrolls, t. 1, Oxford 2000, 434-438; tenże, The Apocrypha and Pseudepigrapha at Qumran, w: J.H. Charlesworth (red.), The Bible and the Dead Sea Scrolls, t. II: The Dead Sea Scrolls and the Qumran Community, Waco 2006, 486-489; P. Muchowski, Komentarze do rękopisów znad Morza Martwego (Seria Judaica i Hebraica, 1), Poznań 2005, 241-250.

7 Zob. J. C. VanderKam, Genesis 1 in Jubilees 2, w: tenże, From Revelation to Canon. Studies in the Hebrew Bible and Second Temple Literature, Boston - Leiden 2002, 503 (= reprint z: DSD 1 (1994) 300-321); tenże, The Manuscript Tradition of the Book of Jubilees, w: G. Boccaccini, i in. (red.), Enoch and the Mosaic Torah: The Evidence of Jubilees, Grand Rapids-Cambridge 2009, 3-21.

8 Zob. J. C. VanderKam, J. T. Milik, Jubilees (DJD 13), 1-22 (4Q216) oraz 35-38 (4Q218); F. Garcia Martinez, E. J. C. Tigchelaar, The Dead Sea Scrolls Study Edition, t. I, Leiden 1999, 458-465 (4Q216) oraz 464-465 (4Q218); zob. też J. C. VanderKam, J. T. Milik, The First Jubilees Manuscript from Qumran Cave 4: A Preliminary Publication, JBL 110 (1991) 243-250; tenże, 4QJub (4Q218) and 4QJub (4Q220): A Preliminary Edition, „Textus” 17 (1994) 43-56. 
fragmentach, które przetrwały, jest bardzo do niego zbliżony. Zachowany tekst syryjski odpowiada Jub 2,2-15 i różni się nieco od wersji greckiej9.

Podobieństwa. W obydwu tekstach (tj. Rdz 1-2,4a; Jub 2) kompozycja materiału jest bardzo podobna: prolog, schemat sześciu dni stworzenia, konkluzja opisu sześciu dni oraz epilog przedstawiający siódmy dzień jako czas błogosławionego i uświęconego odpoczynku. Przedstawia to następujące zestawienie:

\begin{tabular}{|c|c|}
\hline Rdz 1,1-2,4a & Jub 2 \\
\hline \multicolumn{2}{|c|}{ Prolog } \\
\hline $1,1-2$ & 2,1 \\
\hline \multicolumn{2}{|c|}{ Schemat sześciu dni stworzenia } \\
\hline Dzień pierwszy: $1,3-5$ & $2,2-3$ \\
\hline Dzień drugi: $1,6-8$ & 2,4 \\
\hline Dzień trzeci: $1,9-13$ & $2,5-7$ \\
\hline Dzień czwarty: $1,14-19$ & $2,8-10$ \\
\hline Dzień piaty: $1,20-23$ & $2,11-12$ \\
\hline Dzień szósty: $1,24-31$ & $2,13-14$ \\
\hline Konkluzja: 2,1 & $2,15-16$ \\
\hline \multicolumn{2}{|c|}{ Epilog - siódmy dzień } \\
\hline $2,2-4 a$ & $2,17-33$ \\
\hline
\end{tabular}

Podobnie jak w Rdz 1, autor Jub 2 przedstawia kolejne dni stworzenia i szczegółowo wylicza to, co Bóg w każdym z nich powołał do istnienia. Generalnie, poza kilkoma wyjątkami opis poszczególnych dzieł w kolejnych dniach stworzenia jest podobny w obydwu dziełach.

Różnice. Chociaż w obydwu tekstach znajduje się prolog (Rdz 1,1-2; Jub $2,1)$, to jednak różni się on zasadniczo treścią i formą. Przedstawia to następujące zestawienie ${ }^{10}$ :

9 Wydanie: A.-M. Denis, Fragmenta pseudepigraphorum quae supersunt graeca (PVTG 3), Leiden 1970, 71-75; J. C. VanderKam, The Book of Jubilees, t. I, 258-260.

10 Tłumaczenie tekstu w Jub 2, zob. J. C. VanderKam, The Book of Jubilees (CSCO 511; Scriptores Aethiopici 88), t. II, Louvain 1989, 7-15; R. H. Charles, The Book of Jubilees, w: APOT II, 13-15; O. S. Wintermute, Jubilees, 55-58; L. Fusella, Libro dei Giubilei, w: P. Sacchi (red.), Apocrifi dell'Antico Testamento (TEA Religioni e Miti, 17), Milano 2002, 126-131; 


\begin{tabular}{|l|l|}
\hline \multicolumn{1}{|c|}{ Rdz 1,1-2 } & \multicolumn{1}{c|}{ Jub 2,1 } \\
\hline $\begin{array}{l}{ }^{1} \text { Na początku stworzył Bóg niebiosa } \\
\text { i ziemię. }{ }^{2} \text { A ziemia była bezładem } \\
\text { i pustkowiem, i ciemność była nad } \\
\text { powierzchnią otchłani, a duch Boży } \\
\text { unosił się nad powierzchnią wód. }\end{array}$ & $\begin{array}{l}\text { Na rozkaz Pana anioł obecności } \\
\text { powiedział do Mojżesza: Zapisz } \\
\text { wszystkie słowa dotyczące stworzenia } \\
\text { - jak Pan Bóg w sześć dni dokonał } \\
\text { wszystkich swoich dzieł, wszystko, } \\
\text { co stworzył i zachował szabat siódmego } \\
\text { dnia. Uświęcił go po wszystkie wieki } \\
\text { i ustanowił go jako znak dla wszystkich } \\
\text { swoich dzieł. }\end{array}$ \\
\hline
\end{tabular}

W Rdz 1,1-2 jest mowa o „stanie” rzeczywistości, zanim Bóg przystąpił do dzieła stwarzania według schematu sześciu dni. Nie ma tu mowy o tym, kim jest narrator przestawiający dzieje stworzenia świata. Natomiast opis stworzenia w Księdze Jubileuszów jest poprzedzony wstępem (Jub 2,1) oraz obszernym wprowadzeniem (Jub 1), w którym wskazuje się na okoliczności, gdyż jest tutaj mowa o tym, że Mojżesz otrzymał objawienie na górze Synaj, gdzie Bóg przemawiając do Mojżesza zapowiada mu przyszłe odstępstwa, grzechy, pokutę i ocalenie narodu Izraela (Jub 1,7-25). Mojżesz dwa razy otrzymuje nakaz spisania objawienia (Jub 1,4-6.26). Następnie anioł obecności otrzymuje polecenie spisania dla Mojżesza historii z niebiańskich tablic (Jub 1,27-29). We wstępie właściwym (Jub 2,1) jest mowa o aniele obecności, który przekazuje Mojżeszowi objawienie Boże. Następujący po tym wstępie opis stworzenia jest ujęty w formę relacji, którą anioł obecności przekazuje Mojżeszowi. W rezultacie takiej kompozycji przekazu o stworzeniu, w Rdz 1-2,4a bardziej akcentuje się jego aspekt chronologiczny jako „początek”, to w Jub 2 materiał dotyczący stworzenia ma charakter retrospektywny ${ }^{11}$.

Znacząca różnica pojawia się w strukturze literackiej każdego kolejnego dnia stworzenia. W Rdz 1 opis rozpoczyna się od formuły „i powiedział Bóg”, następnie wylicza się to, co Bóg czyni, zaś konkluzję stanowi stwierdzenie „i stał się wieczór, i stał się poranek - dzień (x)”. Natomiast w Jub 2 opis każdego dnia stworzenia rozpoczyna się od podania informacji o kolejnym dniu, a mianowicie „W dniu (x) stworzył / uczynił”, następnie przedstawia się to, co

A. Kondracki, Ksiega Jubileuszów, w: R. Rubinkiewicz (red.), Apokryfy Starego Testamentu, Warszawa 1999, 264-267.

11 Zob. O. H. Steck, Die Aufnahme von Genesis 1 in Jubiläen 2 und 4. Ezra 6, JSJ 8 (1977) 159-160; J. C. VanderKam, Genesis 1 in Jubilees 2, 503-504; J. T. G. A. M. van Ruiten, Primaeval History Interpreted: The Rewriting of Genesis 1-11 in the Book of Jubilees (JSJSup 66), Leiden 2000, 18-20. 
Bóg powołał do istnienia $\mathrm{w}$ danym dniu, a kończy się stwierdzeniem podsumowującym ilość dzieł dokonanych przez Boga w tym dniu, a więc „tych (x) dzieł dokonał w (x) dniu”" ${ }^{2}$. Autor Jub 2 nigdy nie używa formuły „niech stanie się... i stało się tak", która często pojawia się w Rdz 1, co jednak może być wyjaśnione odmienną formą przekazu materiału o stworzeniu. Bardziej intrygującym jest fakt, że w opisie stworzenia znajdującym się w Księdze Jubileuszów brakuje zwrotu „i widział Bóg... że [było to] dobre”, który wielokrotnie pojawia się w Rdz 1 (ww. 4.10.12.18.21.25), jak również stwierdzenia podsumowującego „I widział Bóg wszystko, co uczynił, i oto [było to] bardzo dobre” $(1,31)$. Zamiast podkreślania „dobroci” stworzenia, autor Jub 2 dwukrotnie mówi o tym, że dzieła Boga były „wielkie”, mianowicie w odniesieniu do pierwszego i trzeciego dnia stworzenia. J.C. VanderKam sugeruje, że autor Jub 2 nie czuł potrzeby uwypuklania dobroci tego, co uczynił Bóg, ponieważ było dla niego oczywistym to, że Bóg może czynić wyłącznie dobre rzeczy ${ }^{13}$.

Generalnie materiał znajdujący się w Księdze Jubileuszów zgadza się z Rdz 1 w odniesieniu do poszczególnych dzieł, które Bóg stwarza w kolejne dni, ale istnieją też różnice. Na szczególną uwagę zasługuje opis stworzenia aniołów $\mathrm{w}$ pierwszym dniu, czego nie ma w Księdze Rodzaju ${ }^{14}$. Poza tym, według Jub 2 ziemia została stworzona już w pierwszym dniu, podczas gdy w Rdz 1 (poza prologiem) stwierdza się, że sucha powierzchnia została oddzielona od wód w trzecim dniu. Warto zwrócić uwagę, że autor Jub 2 wymienia ogród Eden wśród dzieł stworzonych przez Boga w trzecim dniu, co jest przykładem (nie jedynym) włączenia przez niego materiału z tradycji jahwistycznej (zob. $\operatorname{Rdz} 2,8)$.

Znaczące różnice pojawiają się w odniesieniu do siódmego dnia. Opis znajdujący się w Rdz 2,1-3 jest bardzo krótki w porównaniu z tym, który pojawia się w Jub 2. W Księdze Rodzaju stwierdza się jedynie, że Bóg odpoczął w tym dniu, pobłogosławił go i uświęcił. Natomiast w Jub 2 następuje bardzo obszerny opis ustanowienia siódmego dnia jako błogosławionego i uświęconego czasu odpoczynku, który zachowuje Bóg, aniołowie oraz Izrael (Jub 2,17-24). Następnie autor Jub 2 opisuje prawa dotyczące zachowania szabatu obowiązujące naród Izraela (Jub 2,25-33).

12 Zob. J. C. VanderKam, Genesis 1 in Jubilees 2, 504; T. Brzegowy, Czytając Heksaemeron (Rdz 1,1-2,3), w: W. Chrostowski (red.), Jak śmierć potężna jest miłość. Księga pamiątkowa ku czci Księdza Profesora Juliana Warzechy SAC (1944-2009), Warszawa-Ząbki 2009, 51.

13 Zob. J. C. VanderKam, Genesis 1 in Jubilees 2, 505.

14 Zob. C. Rowland, The Open Heaven. A Study of Apocalyptic in Judaism and Early Christianity, London 1982, 147. 


\section{Kolejne dni stworzenia - analiza szczegółowa}

Ogólna kompozycja opisów stworzenia w obydwu tekstach (Rdz 1 i Jub 2) jest ujęta w schemat sześciu dni, ale w szczegółach pojawiają się między nimi zarówno podobieństwa, jak i różnice. Struktura obu tekstów pozwala zauważyć, co w każdym z nich jest bardziej akcentowane. W Rdz 1,1-2,4a cała kompozycja jest ujęta $\mathrm{w}$ formę następujących po sobie scen zawierających opis kolejnych dni stworzenia, które kończą się relacją o siódmym dniu jako uwieńczeniu działania Boga. Siódmy dzień - pobłogosławiony i uświęcony przez Boga jest punktem kulminacyjnym całej kompozycji. W Jub 2 wzmianka o siódmym dniu pojawia się już we wprowadzeniu (2,1), gdzie stwierdza się, że Bóg „zachował szabat siódmego dnia, uświęcił go po wszystkie wieki i ustanowił go jako znak dla wszystkich swoich dzieł". Cały opis stworzenia kończy się obszernym omówieniem ustanowienia przez Boga szabatu oraz przepisów dotyczących jego zachowania (Jub 2,17-33). Opowiadanie o stworzeniu w Jub 2 ma formę inkluzji, w której elementem scalającym jest temat szabatu. Ze stworzeniem jest połączony motyw wybrania przez Boga Izraela dla zachowywania szabatu. W ten sposób szabat i wybranie Izraela są ukazane jako istniejące od samego „początku”, tj. ustanowione przez Boga w czasie stworzenia.

DZIEŃ PIERWSZY (Jub 2,2-3; = 4Q216 frag. 1, kol. 5, linie 4-11). Autor Księgi Jubileuszów w opisie pierwszego dnia stworzenia łączy w całość tekst z Rdz 1,1-5, a więc prolog ( $R d z$ 1,1-2) oraz opis pierwszego dnia ( $\operatorname{Rdz} 1,3-5)$.

Połączenie elementów wymienionych w Rdz 1,1-2 z tymi, które znajdują się w Rdz 1,3-5, pozwoliło autorowi Jub 2 wyodrębnić siedem rzeczy stworzonych przez Boga pierwszego dnia, co nawiązuje do symboliki siedmiu dni stworzenia (tj. 6 dni działania + szabat - dzień odpoczynku). Doskonałość dzieł stworzonych - każdej z osobna i wszystkich razem - została podkreślona przez autora $\mathrm{w}$ konkluzji opisu pierwszego dnia stworzenia, gdzie stwierdza, że Bóg uczynił „siedem wielkich dzieł”. Tymi siedmioma dziełami są: niebiosa (= Rdz 1,1); ziemia (= Rdz 1,1.2); wody (= Rdz 1,2); duchy / aniołowie (w Rdz brak wzmianki); otchłanie (= $\mathrm{Rdz} 1,2)$; ciemność (= $\mathrm{Rdz} 1,2.3 .4 .5)$; światło (= $\operatorname{Rdz} 1,3.4 .5)$. Warto zauważyć, że „ciemność” i „światło” z Rdz 1,3 są w Jub 2 uzupełnione przez ,jutrzenkę" i „wieczór”, które pojawiają się w Rdz 1,5 („wieczór” i „poranek”). Nie są one jednak oddzielnymi dziełami stworzenia, ale łączą się z „,iemnością" („wieczór” jako początek nocy) i „światłem” („jutrzenka” 
jako początek dnia $)^{15}$. Warto zwrócić uwagę na kolejność, z jaką zostają wymienione, mianowicie w tekście etiopskim: ciemność - światło - jutrzenka - wieczór (według wzoru: a-b-b'-a'), natomiast w 4Q216 frag. 1, kol. 5, linii 10 jako ciemność - jutrzenka - [światło - wieczór] (według wzoru: a-b’-b-a’).

\begin{tabular}{|c|c|}
\hline Rdz 1,1-5 & Jub 2,2-3 \\
\hline $\begin{array}{l}{ }^{1} \text { Na początku stworzył Bóg niebiosa } \\
\text { i ziemię. }{ }^{2} \text { A ziemia była bezładem } \\
\text { i pustkowiem, i ciemność była nad } \\
\text { powierzchnią otchłani, a duch Boży } \\
\text { unosił się nad powierzchnią wód. }\end{array}$ & \multirow{2}{*}{$\begin{array}{l}2 \text { Ponieważ pierwszego dnia stworzył } \\
\text { niebiosa, które są w górze, ziemię, wody, } \\
\text { i wszystkie duchy, które służą przed } \\
\text { nim, mianowicie aniołów obecności, } \\
\text { aniołów świętości, aniołów duchów } \\
\text { ognia, aniołów duchów wiatrów, } \\
\text { aniołów duchów chmur, ciemności, } \\
\text { śniegu, gradu i mrozu, aniołów głosów, } \\
\text { grzmotów i błyskawic, i aniołów } \\
\text { duchów zimna i upału, zimy, wiosny, } \\
\text { jesieni i lata, i wszystkie duchy jego } \\
\text { stworzeń, które są w niebiosach, na } \\
\text { ziemi i na każdym (miejscu). I [stworzył } \\
\text { również] otchłanie, ciemność i światło, } \\
\text { jutrzenkę i wieczór, które on zamierzył } \\
\text { dzięki wiedzy swego serca. }{ }^{3} \text { Wtedy } \\
\text { ujrzeliśmy Jego dzieła i błogosławiliśmy } \\
\text { Go. I wychwalaliśmy Go z powodu } \\
\text { wszystkich Jego dzieł, ponieważ uczynił } \\
\text { siedem wielkich dzieł pierwszego dnia. }\end{array}$} \\
\hline $\begin{array}{l}{ }^{3} \text { I powiedział Bóg: Niech stanie się } \\
\text { światło! I stało się światło. }{ }^{4} \text { I widział } \\
\text { Bóg światło, że jest dobre. I oddzielił } \\
\text { Bóg światło od ciemności. }{ }^{5} \text { I nazwał } \\
\text { Bóg światło dniem, a ciemność nazwał } \\
\text { nocą. I stał się wieczór, i stał się } \\
\text { poranek - dzień pierwszy. }\end{array}$ & \\
\hline
\end{tabular}

W zachowanym tekście hebrajskim Jub 2 z Qumran (4Q216 frag. 1, kol. 5) zachowały się częściowo określenia kolejnych dzieł, a mianowicie „niebiosa

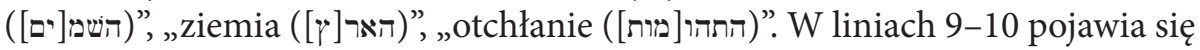
różnica $\mathrm{w}$ terminologii dotyczącej poszczególnych dzieł w stosunku do słownictwa z Rdz 1,1-5. Zamiast ny termin מאפלה, „ciemność; mrok” (hapax legomenon w pismach qumrańskich i w Biblii Hebrajskiej) ${ }^{16}$. Zamiast בקר, "poranek” z Rdz 1, autor Jub 2 używa terminu שחר, ,jutrzenka”.

15 Zob. P. W. Skehan, Jubilees and the Qumran Psalter, CBQ 37 (1975) 345; J.C. VanderKam, The Book of Jubilees, t. II, 8; S. D. Giere, A New Glimpse of Day One. Intertextuality, History of Interpretation, and Genesis 1.1-5 (BZNW 172), Berlin-New York 2009, 173; O. S. Wintermute, Jubilees, 55; L. Fusella, Libro dei Giubilei, 127.

16 Zob. D. J. A. Clines, i in. (red.), The Dictionary of Classical Hebrew, t. V, Sheffield 2001, 122; M. Abegg. Jr i in. (red.), The Dead Sea Scrolls Concordance, t. I: The Non-Biblical 
Warto zauważyć, że dzięki połączeniu wszystkich pięciu wierszy (tj. Rdz 1,1-5) i odniesieniu ich do pierwszego dnia stworzenia, w Księdze Jubileuszów wyraźnie zostaje uwypuklona prawda o tym, że Bóg poprzedza całe stworzenie. Wyrażając przekonanie o tym, że na początku był jedynie Bóg, autor Jub 2 nie wspomina o תהו ובהו, ,bezładzie i pustkowiu” (Rdz 1,2), co może być uważane za pośrednie świadectwo istnienia prawdy o stworzeniu ex nihilo w Jub 2, czyli że Bóg z niczego stworzył cały świat, a nie z jakiejś wcześniej istniejącej nieukształtowanej materii ${ }^{17}$. Należy jednak zauważyć, że w tradycji biblijnej nie pojawiają się wyraźne i jednoznaczne wypowiedzi potwierdzające prawdę o stworzeniu ex nihilo. Co więcej, nawet w późniejszej literaturze rabinicznej znajdują się świadectwa wskazujące na przekonanie o stworzeniu świata z uprzednio istniejącej materii. Nawet tekst w 2 Mch 7,28 („spójrz na niebo i na ziemię, i na wszystkie (rzeczy), które są w nich, wiedz, że z nicze-

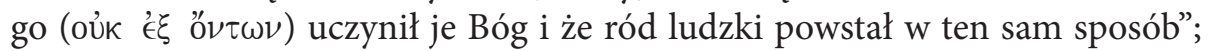
zob. też Mdr 11,17") nie jest w tym względzie całkowicie jednoznaczny. Greckie wyrażenie oủk ' $€ \xi \xi$ ő $\nu \tau \omega \nu$, które zwykle jest tłumaczone jako „z niczego”, może oznaczać „zanim zaistniały” w tym sensie, że Bóg stworzył wszystko jako niebo, ziemię i wszystkie rzeczy zanim one w ten sposób zaistniały. Natomiast prawda o stworzeniu ex nihilo, począwszy od interpretacji 2 Mach 7,28 przez Orygenesa (Comm. Ioannis, I, 17.103; De principiis, II, 1.5) i dziełom Augustyna z Hippony (np. De natura boni contra Manichaeos), jest obecna w tradycji chrześcijańskiej ${ }^{18}$.

W tekście etiopskim pojawia się stwierdzenie, że Bóg stworzył wszystko „dzięki wiedzy swego serca”. W tekście hebrajskim z Qumran brak wyrażenia לבו, „Jego serce" (4Q215 frag. 1, kol. 5, linia 10). Niestety, tekst hebrajski jest w tym miejscu uszkodzony i zachowały się jedynie dwie litery (względnie trzy) Z wyrażenia עד][, ,[dzięki wie]dzy jego". J. T. Milik proponuje, aby zrekon-

Texts from Qumran (Part One), Leiden - Boston 2003, 423.

17 Takie rozumienie sugeruje J. C. VanderKam, Genesis 1 in Jubilees 2, 506. Wyraźne świadectwo istnienia prawdy o stworzeniu ex nihilo w Jub 2 przyjmuje L. Fusella, Libro dei Giubilei, 126.

18 Na temat niejednoznaczności tekstów biblijnych dotyczących prawdy o stworzeniu ex nihilo, zob. np. D. Winston, The Book of Wisdom's Theory of Cosmogony, HR 11 (1971) 186-187; G. Schmuttermayr, Schöpfung aus dem Nichts in 2 Makk 7,28?, BZ.NF 17 (1973) 203-222; G. May, Schöpfung aus dem Nichts: Die Entstehung der Lehre von der Creatio ex nihilo, (AKG 48), Berlin-New York 1978, 6-8; J. A. Goldstein, II Maccabees. A New Translation with Introduction and Commentary (AB 41A), New York 1983; 307-311; tenże, The Origins of the Doctrine of Creation Ex Nihilo, JJS 35 (1984) 127-135; J. J. Collins, Jewish Wisdom in the Hellenistic Age, Edinburgh 1997, 198-199; D. R. Schwartz, 2 Maccabees (CEJL), Berlin-New York 2008, 312-313. 
struować je jako מתו], „[חתו], „dzięki mąd]rości jego”19. Obie propozycje uzupełnienia uszkodzonego tekstu są możliwe, gdyż odwołują się do mądrościowego Hymnu do Stworzyciela (11QPs ${ }^{\mathrm{a}}$ kol. 26, linie 9-15; = 11Q5), w którym pojawiają się obydwa zwroty w kontekście stworzenia, mianowicie w liniach 11-12: „Oddzielając światłość od mroku, jutrzenkę ustanowił dzięki wiedzy swego serca (בדעת לבו)" oraz w linii 14: „ten, który ustanowił świat dzięki swej mądrości (בחוכמתו)" (zob. też 1QH 9,13-14. 19-20). W tych wyrażeniach przyimek = posiada znaczenie narzędziowe w sensie „przez; za pomocą; dzięki” (tj. I instrumentalis). Można przypuszczać, że podobnie jak w hymnie z Qumran (11Q5 26,9-15) występujące w Jub 2 terminy mądrościowe (רעת, „wiedza”; ,חובגąrość”) w kontekście stworzenia są wczesnym świadectwem tradycji egzegetycznej łączącej tekst w Prz 8,22 („JHWH stworzył mnie, początek (ראשית) swojej drogi, przed dziełami swoimi od dawna") z Rdz 1,1, która polega

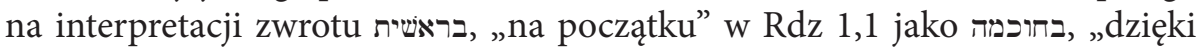
mądrości”. Taka interpretacja pojawia się w literaturze targumicznej (Tg. Neofiti I, Tg. Fragmentaryczny) oraz w pismach Filona z Aleksandrii. Poprzez wprowadzenie wyrażenia „dzięki wiedzy swego serca” autor Jub 2 wyraża myśl, że wszystko zostało stworzone jako dobre i wspaniałe, ponieważ boska mądrość towarzyszyła Bogu w stwórczej działalności ${ }^{20}$.

Szczególną pozycję w opisie pierwszego dnia zajmują duchy / aniołowie, co zostało wyrażone dzięki układowi kolejnych dzieł stworzenia. Autor Jub 2 wyróżnia aniołów poprzez umieszczenie ich w środku siedmiu dzieł stworzonych pierwszego dnia. Przedstawia to poniższe zestawienie uwypuklające istnienie w układzie całego materiału schematu (tj. według wzoru: 3 // 1 // 3):

19 Zob. J. C. VanderKam, J. T. Milik, Jubilees (DJD 13), 16; F. Garcia Martinez, E. J. C. Tigchelaar, The Dead Sea Scrolls Study Edition, t. I, Leiden 1999, 460.

20 Zob. M. Parchem, Hymn do Stworzyciela - psalm mądrościowy z Qumran (11Q5 26,9-15), w: Fs. dla W. Chrostowskiego (artykuł w druku); J. C. VanderKam, Genesis 1 in Jubilees 2, 509; F. Garcia Martinez, Creation in the Dead Sea Scrolls, w: G. H. van Kooten (red.), The Creation of Heaven and Earth. Re-Interpretation of Genesis I in the Context of Judaism, Ancient Philosophy, Christianity, and Modern Physics (Themes in Biblical Narrative. Jewish and Christian Traditions, 8), Leiden 2005, 69; tenże, The Genesis of Alexandria, the Rabbis and Qumran, w: F. Garcia Martinez, E. J. C. Tigchelaar (red.), Qumranica Minora II. Thematic Studies on the Dead Sea Scrolls (STDJ 64), Leiden 2007, 248-249. 


\begin{tabular}{|c|c|}
\hline $\begin{array}{l}\text { - niebiosa } \\
- \text { ziemia } \\
- \text { wody }\end{array}$ & 3 dzieła \\
\hline- Aniołowie & 1 dzieło \\
\hline $\begin{array}{l}- \text { otchłanie } \\
- \text { ciemność } \\
- \text { mrok }\end{array}$ & 3 dzieła \\
\hline \multicolumn{2}{|c|}{ Razem: 7 dzieł } \\
\hline
\end{tabular}

Znajdujący się w Jub 2 opis stworzenia duchów / aniołów, o których brak wzmianki w Rdz 1, stanowi zapewne interpretację wyrażenia רוח אלהים, „duch Boży” z Rdz 1,2. Wskazuje na to określenie istot niebiańskim terminem „duchy" na początku i końcu opisu w Jub 2,2 ${ }^{21}$. W 4Q216 frag. 1, kol. 5, linii 9 zachował się hebrajski termin רוחות, „duchy”, który pojawia się w podsumowaniu opisu wszystkich kategorii aniołów: [כל], „wוחות בריותו, ,wszystkie duchy jego stworzeń". Autor Jub 2 wymienia siedem kategorii aniołów, co odpowiada siedmiu dziełom powołanym do istnienia przez Boga pierwszego dnia oraz ogólnemu podziałowi całego stworzenia na siedem dni, tj. sześć dni stwarzania i siódmy dzień odpoczynku. W tekście etiopskim wylicza się następujące kategorie aniołów, które są potwierdzone - tam gdzie zachował się tekst - w 4Q216 frag. 1, kol. 5, linie 5-82

\begin{tabular}{|c|c|}
\hline Tekst etiopski & Tekst hebrajski \\
\hline - aniołowie obecności & , aniołowie obecności” , [מלאכי] הפנים \\
\hline - aniołowie świętości & , , , ומלאכי הקו [דש] aniołowie świętości” \\
\hline
\end{tabular}

21 Zob. A. Epstein, Le livre des Jubiles, Philon et le midrasch Tadsche, REJ 21 (1890) 84-85; R. H. Charles, The Book of Jubilees or the Little Genesis, London 1902, 10-12; J. C. VanderKam, Genesis 1 in Jubilees 2, 506; J. T. G. A. M. van Ruiten, Primaeval History Interpreted, 25; F. Garcia Martinez, Creation in the Dead Sea Scrolls, 68-69. Warto zauważyć, że w literaturze rabinicznej stworzenie aniołów jest umieszczane w różnych dniach stworzenia, między innymi w drugim lub piątym, zaś punktem wyjścia w egzegezie stało się wyrażenie וכל צבאם , , , każdy ich zastęp” w Rdz 2,1, który rozumiano jako odnoszący się do „Zastępów” aniołów (np. GenR 1,9; Tg. Ps.-J. do Rdz 1,26).

22 Zob. J. C. VanderKam, The Book of Jubilees, t. II, 7-8; tenże, Genesis 1 in Jubilees 2, 507. 


\begin{tabular}{|c|c|}
\hline Tekst etiopski & Tekst hebrajski \\
\hline - aniołowie duchów ognia & $\begin{array}{l}\text { W 4Q216 zachowały się jedynie dwie litery: } \\
{[\ldots] \text {.... Tekst grecki czyta „aniołowie chwały” }} \\
\text { (Epifaniusz). }\end{array}$ \\
\hline - aniołowie duchów wiatrów & W 4Q216 tekst nie zachował się. \\
\hline $\begin{array}{l}\text { - aniołowie duchów chmur, } \\
\text { ciemności, śniegu, gradu i mrozu }\end{array}$ & 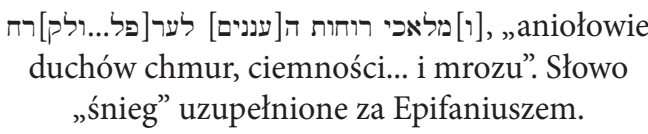 \\
\hline $\begin{array}{c}\text { - aniołowie głosów, grzmotów } \\
\text { i błyskawic }\end{array}$ & , , ,ממלאכי הקולו]ת], aniołowie głosów” \\
\hline $\begin{array}{l}\text { - aniołowie duchów zimna } \\
\text { i upału, zimy, wiosny, jesieni i lata }\end{array}$ & 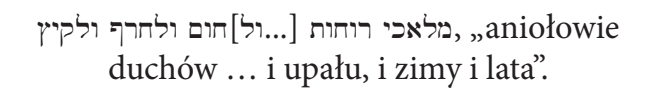 \\
\hline
\end{tabular}

Według Jub 2,3 aniołowie wysławiają Boga za dzieło stworzenia: „Wtedy ujrzeliśmy Jego dzieła i błogosławiliśmy Go. I wychwalaliśmy Go z powodu wszystkich Jego dzieł, ponieważ uczynił siedem wielkich dzieł pierwszego dnia”. Wzmianka o uwielbieniu Boga przez aniołów w pierwszym dniu stworzenia pojawia się również w hymnie z Qumran: „Gdy zobaczyli to wszyscy posłańcy jego, wtedy śpiewali głośno, ponieważ ukazał im to, czego nie znali” (11Q5 kol. 26, linia 12). Jednakże inaczej niż w hymnie z Qumran, narratorem w Jub 2 jest anioł obecności przekazujący Mojżeszowi objawienie dane od Boga (zob. Jub 2,1), dlatego wypowiedź jest sformułowana w pierwszej osobie. Warto jednak zauważyć, że pojawiające się w tekście etiopskim czasowniki („błogosławić”, „wychwalać”) są synonimami hebrajskiego רנין , „śpiewać głośno (radośnie)", który pojawia się w hymnie qumrańskim. Niestety, żaden czasownik odnoszący się do wysławiania Boga przez aniołów nie zachował się w 4Q216 frag. 1, kol. 5, linie 10-11. Najprawdopodobniej obydwa teksty nawiązują do Hi 38,7, gdzie znajduje się wzmianka o śpiewie aniołów w kontekście stworzenia i występuje czasownik רנן, „śpiewać głośno (radośnie): „gdy radośnie śpiewały razem gwiazdy poranku, i wznosili okrzyki wszyscy synowie Boży". Poprzez wzmiankę o błogosławieniu i wychwalaniu Boga za dzieło stworzenia, autor Jub 2,3 uwypukla prawdę o Bogu jako jedynym Stwórcy odbierającym uwielbienie od aniołów, których powołał do istnienia. W ten sposób zostaje we wszystkich tych tekstach (Hi 38,7; 11Q5 26,9-15; Jub 2) wyrażona myśl o absolutnej władzy Boga, któremu hołd oddają wszystkie istoty niebiańskie (zob. Ps 103,20-22; 148,1-3; Syr 42,16-17; 1QM 12,1; Pieśni ofiary szabatowej) ${ }^{23}$.

23 Zob. M. Parchem, Hymn do Stworzyciela - psalm mądrościowy z Qumran (11Q5 26,9-15), w: Fs. dla W. Chrostowskiego (artykuł w druku); P. W. Skehan, Jubilees and the 
DZIEŃ DRUGI (Jub 2,4; = 4Q216 frag. 1, kol. 5, linie 12-14). W opisie drugiego dnia zachodzą znaczące różnice między Jub 2,4 oraz Rdz 1,6-8. W tym dniu Bóg stwarza tylko jedno dzieło.

\begin{tabular}{|c|c|}
\hline $\operatorname{Rdz} 1,6-8$ & Jub 2,4 \\
\hline $\begin{array}{l}{ }^{6} \text { I powiedział Bóg: Niech stanie się fir- } \\
\text { mament w środku wód i niech zostaną } \\
\text { oddzielone wody od wód! }{ }^{7} \text { I uczynił } \\
\text { Bóg firmament i oddzielił wody, któ- } \\
\text { re są pod firmamentem od wód, które } \\
\text { są nad firmamentem. I stało się tak. } \\
\text { I nazwał Bóg firmament niebiosami. } \\
\text { I stał się wieczór, i stał się poranek - } \\
\text { dzień drugi. }\end{array}$ & $\begin{array}{l}{ }^{4} \text { Drugiego dnia uczynił firmament mię- } \\
\text { dzy wodami. A wody zostały rozdzielone } \\
\text { tego dnia. Połowa } \mathrm{z} \text { nich wzniosła się do } \\
\text { góry, a połowa z nich opadła poniżej fir- } \\
\text { mamentu, który był w pośrodku ponad } \\
\text { powierzchnią całej ziemi. I tylko to dzieło } \\
\text { zostało dokonane dnia drugiego. }\end{array}$ \\
\hline
\end{tabular}

W obu tekstach jest mowa o stworzeniu firmamentu (hebr. רקיע). Tekst hebrajski Jub 2,4 zachował się w stanie bardzo fragmentarycznym (4Q216 frag. 1, kol. 5, liniach 12-13) i brak w nim słowa „firmament”. Jednakże w tekście greckim przechowanym u Epifaniusza występuje termin $\sigma \tau \epsilon \rho \epsilon \epsilon \mu \alpha$, „firmament”, którym autorzy LXX tłumaczą hebrajskie słowo רקיע w Rdz 1,6-8. Według Rdz 1,1-8, Bóg stworzył firmament i nazwał go „niebiosami (השמים)”. Dla autora Jub 2,4 stwarza to problem, ponieważ w Księdze Jubileuszów Bóg stworzył niebiosa już pierwszego dnia (Jub 2,2), stąd nie było potrzeby powtórnego ich stwarzania $\mathrm{w}$ drugim dniu. $\mathrm{W}$ rezultacie zmiany, którą autor Jub 2 wprowadził do swojego tekstu w relacji do $\operatorname{Rdz} 1,6-8$, powstał nowy element kosmosu, który jest różny od niebios z tekstu biblijnego ${ }^{24}$.

DZIEŃ TRZECI (Jub 2,5-7; = 4Q216 frag. 1, kol. 6, linie 2-4). W opisie trzeciego dnia w Jub 2 pojawia się jedyne bezpośrednie odniesienie do tekstu biblijnego ( $\mathrm{Rdz} 1,9)$, mianowicie do Bożego polecenia skierowanego do wód, którego rezultatem stało się wyłonienie suchej powierzchni.

Qumran Psalter (11QPs $\left.{ }^{a}\right)$, 344; O. S. Wintermute, Jubilees, 55; J. C. VanderKam, The Book of Jubilees, 8-9; tenże, Genesis 1 in Jubilees 2, 509-510; J. T. G. A. M. van Ruiten, Primaeval History Interpreted, 26-27.

24 Zob. O. H. Steck, Die Aufnahme von Genesis 1 in Jubiläen 2 und 4. Ezra 6, 167; J. C. VanderKam, Genesis 1 in Jubilees 2, 510; J. T. G. A. M. van Ruiten, Primaeval History Interpreted, 28. 


\begin{tabular}{|c|c|}
\hline Rdz 1,9-13 & Jub $2,5-7$ \\
\hline $\begin{array}{l}9 \text { I powiedział Bóg: Niech zbiorą } \\
\text { się wody spod niebios w jedno miejsce } \\
\text { i niech ukaże się sucha powierzchnia! } \\
\text { I stało się tak. }{ }^{10} \text { I nazwał Bóg suchą po- } \\
\text { wierzchnię ziemią, a zbiorowisko wód } \\
\text { nazwał morzami. I widział Bóg, że [było } \\
\text { to] dobre. }{ }^{11} \text { I powiedział Bóg: Niech za- } \\
\text { zieleni się ziemia roślinami zielonymi, } \\
\text { trawą dającą nasienie, drzewem owo- } \\
\text { cowym dającym owoc, według swego } \\
\text { rodzaju, w których są nasiona na ziemi. } \\
\text { I stało się tak. }{ }^{12} \text { I wydała ziemia rośliny } \\
\text { zielone: trawę dającą nasienie według } \\
\text { swego rodzaju i drzewo dające owoc, } \\
\text { w którym jest nasienie, według swego } \\
\text { rodzaju. I widział Bóg, że [było to] do- } \\
\text { bre. }{ }^{13} \text { I stał się wieczór, i stał się poranek } \\
\text { - dzień trzeci. }\end{array}$ & $\begin{array}{l}5 \text { Trzeciego dnia uczynił tak, jak po- } \\
\text { wiedział wodom, żeby zebrały się z po- } \\
\text { wierzchni całej ziemi w jedno miejsce, } \\
\text { i żeby ukazała się sucha powierzchnia. } \\
{ }^{6} \text { I wody uczyniły tak, jak im powiedział. } \\
\text { Zebrały się z całej powierzchni ziemi } \\
\text { poza firmamentem i ukazała się sucha } \\
\text { powierzchnia. }{ }^{7} \text { I tego dnia stworzył On } \\
\text { wszystkie morza, każde na swoim miej- } \\
\text { scu, wszystkie rzeki, i wszystkie zbio- } \\
\text { rowiska wód w górach i na całej ziemi, } \\
\text { wszystkie jeziora, rosę na całej ziemi, } \\
\text { nasienie, które jest zasiewane według } \\
\text { wszelkiego swego rodzaju i wszystko to, } \\
\text { co jest jadalne, drzewa rodzące owoce } \\
\text { i lasy, ogród Eden i w Edenie wszystko } \\
\text { w obfitości. Te cztery wielkie rodzaje } \\
\text { uczynił dnia trzeciego. }\end{array}$ \\
\hline
\end{tabular}

Chociaż autor Jub $2 \mathrm{w}$ podobny sposób przedstawia oddzielenie wód od suchej powierzchni, czego rezultatem było wyłonienie się ziemi, to jednak rezultaty tej czynności Boga różnią się nieco od tych, które ukazuje Rdz 1,9-13. Według tekstu biblijnego, Bóg nazwał wody morzami, zaś suchą powierzchnię ziemią. Tymczasem w Jub 2 po oddzieleniu wód i wyłonieniu się suchej powierzchni, Bóg stwarza różnego rodzaju zbiorowiska wód, mianowicie morza, rzeki, wody w górach, jeziora, rosę (Jub 2,7), co wydaje się być interpretacją uzupełniającą do biblijnego terminu ימים, „wody”. W obu tekstach jest mowa o stworzeniu roślin dających nasienie oraz drzew rodzących owoce, przy czym autor Jub 2 dodaje jeszcze „lasy” (יערים[ה w 4Q216 frag. 1, kol. 6, linia 3). Autor Jub 2 unika sformułowania, że „ziemia wydała (ותוצא הארץ) rośliny zielone” ( $\operatorname{Rdz} 1,12)$, które mogłoby sugerować, że ziemia jest sama z siebie zdolna coś „stworzyć", a to byłoby pewnego rodzaju dwuznacznością w kontekście prawdy o Bogu jako jedynym Stwórcy wszystkiego. W stwierdzeniu podsumowującym trzeci dzień autor Jub 2 stwierdza, że Bóg uczynił cztery wielkie dzieła. Trudno jednoznacznie stwierdzić, o jakie konkretnie dzieła chodzi. Z pewnością nie są to wody, które zostały stworzone pierwszego dnia. Najprawdopodobniej są nimi: sucha ziemia, różne rodzaje wód lądowych, roślinność wydająca nasienie i owoce oraz lasy, ogród Eden ${ }^{25}$. Warto zwrócić uwagę, że według Jub 2 ziemia

25 Zob. O. S. Wintermute, Jubilees, 56; J. C. VanderKam, Genesis 1 in Jubilees 2, 511. 
również została stworzona już pierwszego dnia, ale tutaj być może autor odróżnia ziemię w sensie całości od suchej powierzchni wydającej roślinność.

Spośród czterech dzieł stworzonych trzeciego dnia jedno wzbudza szczególną uwagę, mianowicie „ogród Eden” (ן ג ג ע ע 4 4Q216 frag. 1, kol. 6, linia 3). W Księdze Rodzaju o ogrodzie Eden wspomina się w tradycji uznawanej przez wielu uczonych za jahwistyczną (J): „I zasadził JHWH Bóg ogród w Eden na wschodzie" (Rdz 2,8). J. C. VanderKam sugeruje, że mogły być dwa powody, dla których autor Jub 2 umieszcza stworzenie ogrodu Eden w trzecim dniu ${ }^{26}$. Po pierwsze, przekonanie o tym, że ogród Eden musiał zostać stworzony w trzecim dniu mogło być wynikiem połączenia teksu w Rdz 1,11-12 opisującego rośliny dające nasienie i drzewa rodzące owoce z $\mathrm{Rdz} 2,9.16-17$, gdzie jest mowa o drzewach rodzących owoce, $w$ tym o drzewie życia i drzewie poznania dobra i zła, które znajdowały się w ogrodzie Eden. Według autora Jub 2, skoro rośliny i drzewa rodzących owoce zostały stworzone $\mathrm{w}$ trzecim dniu, to również musiał być stworzony ogród Eden, w którym te drzewa zostały umieszczone. Po drugie, przeniesienie ogrodu Eden z kontekstu Rdz 2,8 do Rdz 1 mogło być rezultatem tradycji egzegetycznej dotyczącej wyrażenia מקדם, „na wschodzie”, rozumianego w sensie „przed; uprzednio”, której istnienie jest poświadczone w Midraszu do Księgi Rodzaju, gdzie jest mowa o tym, że ogród Eden został stworzony trzeciego dnia, a więc przed Adamem, który został stworzony szóstego dnia (GenR 15,3). O stworzeniu rajskiego ogrodu w trzecim dniu jest również mowa w Księdze Henocha słowiańskiej (2 Hen 30,1; w recenzji dłuższej) oraz w midraszu Bereszit Rabba $15^{27}$. W 4 Ezd 3,6 stwierdza się, że ogród rajski został stworzony przed stworzeniem świata, co stało się powszechnym przekonaniem występującym w literaturze rabinicznej, gdzie ogród Eden jest jedną z siedmiu rzeczy stworzonych przez Boga zanim powstał świat (np. b.Nedarim 39b; b.Pesachim 54a; PRE 3) $)^{28}$.

DZIEŃ CZWARTY (Jub 2,8-10; = 4Q216 frag. 1, kol. 6, linie 5-10). W opisie czwartego dnia stworzenia autor Jub 2 wymienia te same trzy dzieła jak w Rdz 1,14-19, ale przeredagowuje cały materiał, uwypuklając inny jego aspekt.

26 J. C. VanderKam, Genesis 1 in Jubilees 2, 511-512; J. T. G. A. M. van Ruiten, Primaeval History Interpreted, 34-35.

27 Zob. R. H. Charles, The Book of Jubilees, w: APOT II, 14; O. S. Wintermute, Jubilees, 56; J. C. VanderKam, Genesis 1 in Jubilees 2, 512.

28 Szerzej na ten temat, zob. M. E. Stone, Fourth Ezra. A Commentary on the Book of Fourth Ezra (Hermeneia), Minneapolis 1990, 68-69. 


\begin{tabular}{|c|c|}
\hline Rdz 1,14-19 & Jub 2,8-10 \\
\hline $\begin{array}{l}14 \text { I powiedział Bóg: Niech staną się } \\
\text { światła na firmamencie niebios, aby } \\
\text { oddzielały dzień od nocy, i będą znaka- } \\
\text { mi dla pór czasu, dla dni i lat. }{ }^{15} \text { I będą } \\
\text { światłami na firmamencie niebios, } \\
\text { aby świeciły nad ziemią. I stało się tak. } \\
16 \text { I uczynił Bóg dwa wielkie światła: } \\
\text { światło większe, aby rządziło dniem, } \\
\text { i światło mniejsze, aby rządziło nocą, } \\
\text { i gwiazdy. }{ }^{17} \text { I umieścił je Bóg na skle- } \\
\text { pieniu niebios, aby świeciły nad ziemią, } \\
18 \text { i aby rządziły w dzień i w nocy, i aby } \\
\text { oddzielały światło od ciemności. I wi- } \\
\text { dział Bóg, że [było to] dobre. }{ }^{19} \text { I stał } \\
\text { się wieczór, i stał się poranek - dzień } \\
\text { czwarty. }\end{array}$ & $\begin{array}{l}{ }^{8} \text { Czwartego dnia uczynił słońce, księżyc } \\
\text { i gwiazdy. Umieścił je na firmamencie } \\
\text { niebios, aby świeciły nad całą ziemią, aby } \\
\text { rządziły dniem i nocą, i aby oddzielały } \\
\text { światło od ciemności. }{ }^{9} \text { I Pan ustanowił } \\
\text { słońce jako wielki znak nad ziemią dla } \\
\text { ustalenia dni, szabatów, miesięcy, świąt, } \\
\text { lat, siedmioleci, jubileuszy i wszystkich } \\
\text { okresów lat. }{ }^{10} \text { I ono oddziela światło } \\
\text { od ciemności, aby wszystko, co kiełkuje } \\
\text { i wzrasta na ziemi, mogło dobrze się roz- } \\
\text { wijać. Te trzy dzieła uczynił dnia czwar- } \\
\text { tego. }\end{array}$ \\
\hline
\end{tabular}

W obydwu tekstach pojawia się opis tych samych trzech świateł na firmamencie niebios, a więc słońca, księżyca i gwiazd, ale pojawiają się między nimi pewne różnice. W Księdze Rodzaju dzieła stworzone w czwartym dniu są najpierw określone ogólnie jako מארת, ,światła; ciała świecące”, a następnie autor wymienia je, używając nazw opisowych, mianowicie המאור הגדל, ,światło wielkie” oraz המאור הקטן, „światło małe”. Jedynie trzecie dzieło nazywa używając właściwej nazwy, mianowicie הכוכבים, „gwiazdy”. Natomiast autor Jub 2 wymieniając ciała świecące używa nazw, a więc określa je terminami: słońce, księżyc i gwiazdy. Zachował się tekst hebrajski: השש[ש ואת הירח ואת הכוכבים], „[sło]ńce i księżyc i gwiazdy" (4Q216 frag. 1, kol. 6, linia 5). Według Rdz 1,14, główna funkcja polegająca na wyznaczeniu pór czasu, dni i lat, jest odniesiona do wszystkich świateł. Natomiast w Jub 2,9 odpowiedzialnym za wyznaczanie kolejnych okresów czasu jest tylko słońce. Autor znacznie poszerza listę tego, co ustala słońce wymieniając dni, szabaty, miesiące, święta, lata, siedmiolecia, jubileusze i wszystkie okresy lat. W 4Q216 zachowało się jedynie kilka nazw - niestety w stanie bardzo fragmentarycznym - stwierdzających, że słońce jest wielkim znakiem (אות גד] ילול) dla

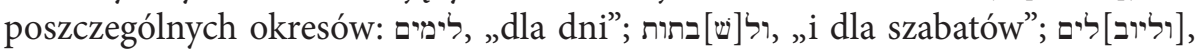
„i dla jubileuszów”; לכול תק[ופות השנים, „i dla wszystkich okresów lat” (kol. 6, linie 7-8). W ten sposób autor Jub 2 uwypukla znaczenie kalendarza słonecznego, natomiast całkowicie ignoruje kalendarz księżycowy. Warto zauważyć, że nawet miesiące zostają podporządkowane słońcu. W Księdze Rodzaju brak takiego podkreślenia roli słońca, a przypisanie wyznaczania pór roku i okresów 
świątecznych słońcu i księżycowi może wskazywać, że dla kapłańskiego autora Rdz 1 do zaakceptowania jest zarówno kalendarz słoneczny, jak i księżycowy. Wiadomo również, że wspólnota z Qumran - o kapłańskiej proweniencji - posługiwała się kalendarzem słonecznym, ale nie pomijała księżycowego, co widać z tekstów synchronizujących oba kalendarze (np. Miszmarot, różne teksty kalendarzowe). Z pism qumrańskich wynika, że kalendarz - a zatem także czas obchodzenia świąt - był jednym z podstawowych powodów odłączenia się wspólnoty esseńskiej od reszty judaizmu (np. CD 3,12-15; 6,11-12; 11Q5 27,4-8) ${ }^{29}$. O stosowaniu kalendarza słonecznego obok księżycowego w okresie Drugiej Świątyni świadczy także Księga astronomiczna (1 Hen 72-82), której powstanie datuje się na koniec III w. przed Chr. Można przypuszczać, że Księga Jubileuszów, która powstała w okresie ścierania się różnych koncepcji dotyczących używania obu kalendarzy, w sposób radykalny opowiada się za kalendarzem słonecznym, a czyni to nie tylko poprzez uwypuklenie roli słońca, ale również poprzez całkowite odrzucenie księżyca w ustaleniach kalendarzowych. Autor Jub 2, uwypuklając z emfazą dominującą rolę słońca, stwierdza, że dzięki niemu wszystko właściwie rozwija się na ziemi, zarówno rośliny, jak i zwierzęta (Jub 2,10 oraz 2,12). Innymi słowy, słońce nie tylko reguluje ustalenia kalendarzowe, ale również zapewnia to wszystko, czego do życia potrzebują istoty żyjące. Należy również zauważyć, że dla podkreślenia rangi słońca zostaje ono nazwane „wielkim znakiem” (Jub 2,9), co w opisie stworzenia w Księdze Jubileuszów odnosi się jeszcze tylko do szabatu $(\text { Jub } 2,17)^{30}$.

29 Szerzej na temat obu kalendarzy i ich używania w judaizmie, R. T. Beckwith, Calendar and Chronology, Jewish and Christian (AGAJU 23), Leiden 1996; J. C. VanderKam, Calendars in the Dead Sea Scrolls: Measuring Time (LDSS), London-New York 1998; J. BenDov, Head of All Years: Astronomy and Calendars at Qumran in Their Ancient Context (STDJ 78), Leiden 2008; P. Muchowski, Komentarze do rękopisów znad Morza Martwego, 38-40, 223-239.

30 Zob. R. H. Charles, The Book of Jubilees, w: APOT II, 14; J. C. VanderKam, Genesis 1 in Jubilees 2, 513; L. Fusella, Libro dei Giubilei, 128; E. J. C. Tigchelaar, Lights Serving as Signs for Festivals (Genesis 1,14b) in Enuma Eliš and Early Judaism, w: G. H. van Kooten (red.), The Creation of Heaven and Earth. Re-Interpretation of Genesis I in the Context of Judaism, Ancient Philosophy, Christianity, and Modern Physics (Themes in Biblical Narrative. Jewish and Christian Traditions, 8), Leiden 2005, 47; J. T. G. A. M. van Ruiten, Primaeval History Interpreted, 39-40; J. Ben-Dov, Tradition and Innovation in the Calendar of Jubilees, w: G. Boccaccini i in. (red.), Enoch and the Mosaic Torah: The Evidence of Jubilees, Grand Rapids - Cambridge 2009, 276-293. 
DZIEŃ PIĄTY (Jub 2,11-12; = 4Q216 frag. 1, kol. 6, linie 11-15). W opisie piątego dnia stworzenia autor Jub 2 wymienia dzieła podobnie jak w Rdz 1, ale różni się w niektórych szczegółach.

\begin{tabular}{|c|c|}
\hline Rdz 1,20-23 & Jub 2,11-12 \\
\hline $\begin{array}{l}{ }^{20} \text { I powiedziałBóg: Niech zaroją się wody } \\
\text { rojem istot żyjących, a ptactwo niech } \\
\text { lata nad ziemią, na sklepieniu niebios! } \\
{ }^{21} \text { I stworzył Bóg wielkie potwory wod- } \\
\text { ne i wszelką pływającą istotę żyjącą, } \\
\text { którą zaroiły się wody, według ich ro- } \\
\text { dzaju, oraz wszelkie ptactwo skrzydlate } \\
\text { według swego rodzaju. I widział Bóg, } \\
\text { że [było to] dobre. }{ }^{22} \text { I pobłogosławił } \\
\text { im Bóg, mówiąc: Bądźcie płodne i roz- } \\
\text { mnażajcie się i napełniajcie wody w mo- } \\
\text { rzach, a ptactwo niech mnoży się na zie- } \\
\text { mi. }{ }^{23} \text { I stał się wieczór, i stał się poranek } \\
\text { - dzień piąty. }\end{array}$ & $\begin{array}{l}{ }^{11} \text { Piątego dnia stworzył wielkie potwory } \\
\text { wodne w morskich głębinach - to były } \\
\text { pierwsze istoty cielesne stworzone przez } \\
\text { Jego ręce - wszystkie ryby, które poru- } \\
\text { szają się w wodach, wszystkie gatunki } \\
\text { ptactwa fruwającego. }{ }^{12} \text { I słońce wzeszło } \\
\text { nad nimi, aby mogły się rozwijać, i nad } \\
\text { wszystkim, co było na ziemi, nad wszyst- } \\
\text { kim, co wschodzi na ziemi, nad każdym } \\
\text { drzewem, co rodzi owoce, i nad każdą } \\
\text { istotą cielesną. Te trzy rodzaje uczynił } \\
\text { dnia piątego. }\end{array}$ \\
\hline
\end{tabular}

W podsumowaniu autor Jub 2 stwierdza, że w piątym dniu Bóg stworzył trzy dzieła, którymi są potwory morskie, ryby i ptaki ${ }^{31}$. Szczególną uwagę autor Jub 2 poświęca potworom morskim, które umieszcza w swoim opisie na pierwszym miejscu, podczas gdy w Rdz 1,21 są one wymienione po istotach żyjących $\mathrm{w}$ wodach oraz ptakach. Wyjątkową pozycję potworów morskich podkreśla dopowiedzenie, że „były to pierwsze istoty cielesne stworzone przez Jego ręce” (Jub $2,11)$. Podobnie jak w opisie trzeciego dnia stworzenia, autor Jub 2 unika sformułowania, w którym Bóg rozkazuje, aby „wody zaroiły (ישרצי המים) się rojem istot żywych" (Rdz 1,20). Chociaż jest to polecenie Boga, to przypisanie wodom możliwości „stworzenia” czegokolwiek może sugerować pewną dwuznaczność, zwłaszcza w kontekście podkreślanej przez autora Jub 2 prawdy o tym, że jedynie Bóg jest Stwórcą wszystkiego. Z tego powodu w Jub 2 stwierdza się jednoznacznie, że to sam Bóg bezpośrednio stworzył potwory morskie, ryby, ptaki i wszystko ${ }^{32}$. Największą różnicą w stosunku do Rdz 1 jest to, że w Jub 2,11-12 brak błogosławieństwa Bożego w odniesieniu istot żywych stworzonych piątego dnia i zapewniającego im płodność, które znajduje się w Rdz 1,22. Trudno jednoznacznie wskazać na przyczynę tego pominięcia, być może było ono spowo-

31 Zob. O. S. Wintermute, Jubilees, 56; J.C. VanderKam, Genesis 1 in Jubilees 2, 513.

32 Zob. J. C. VanderKam, Genesis 1 in Jubilees 2, 513. 
dowane powtórnym (zob. Jub 2,10) podkreśleniem roli słońca, które zapewnia właściwy rozwój roślinom i wszystkim istotom żyjącym (Jub 2,12) 33 .

DZIEŃ SZÓSTY (Jub 2,13-14; = 4Q216 frag. 1, kol. 7, linie 1-4). W opisie szóstego dnia, w którym Bóg stwarza różne rodzaje zwierząt oraz ludzi, zachodzą znaczące różnice w stosunku do Rdz 1,24-31.

\begin{tabular}{|c|c|}
\hline Rdz 1,24-31 & Jub 2,13-14 \\
\hline $\begin{array}{l}24 \text { I powiedział Bóg: Niech ziemia wyda istotę } \\
\text { żyjącą według swego rodzaju: bydło, i zwierzęta } \\
\text { pełzające i zwierzę lądowe według swego rodza- } \\
\text { ju! I stało się tak. }{ }^{25} \text { I uczynił Bóg zwierzę lądo- } \\
\text { we według swego rodzaju, i bydło według swego } \\
\text { rodzaju, i wszelkie zwierzę pełzające ziemi według } \\
\text { swego rodzaju. I widział Bóg, że [było to] dobre. }{ }^{26} \\
\text { I powiedział Bóg: Uczyńmy ludzi na nasz obraz, } \\
\text { podobnych do nas. I niech panują nad rybami mo- } \\
\text { rza, i nad ptactwem niebios, i nad bydłem, i nad } \\
\text { całą ziemią i nad wszelkim płazem pełzającym po } \\
\text { ziemi! }\end{array}$ & $\begin{array}{l}13 \text { Szóstego dnia stworzył } \\
\text { wszystkie zwierzęta ziemskie, } \\
\text { wszelkie bydło i to wszyst- } \\
\text { ko, co porusza się na ziemi. } \\
14 \text { A po tym wszystkim uczynił } \\
\text { ludzi, jako mężczyznę i kobie- } \\
\text { tę uczynił ich. I dał mu pano- } \\
\text { wanie nad wszystkim na ziemi, } \\
\text { i w morzach, i nad stworzenia- } \\
\text { mi fruwającymi, nad zwierzę- } \\
\text { tami, bydłem, wszystkim, co } \\
\text { porusza się na ziemi i nad całą } \\
\text { ziemią. Nad tym wszystkim } \\
\text { dał mu panowanie. Te cztery } \\
\text { rodzaje uczynił dnia szóstego. }\end{array}$ \\
\hline $\begin{array}{l}{ }^{27} \text { I stworzył Bóg człowieka na swój obraz, na ob- } \\
\text { raz Boga go stworzył, mężczyzną i kobietą stwo- } \\
\text { rzył ich. }{ }^{28} \text { I pobłogosławił im Bóg, i powiedział } \\
\text { Bóg do nich: Bądźcie płodni i rozmnażajcie się } \\
\text { i napełniajcie ziemię. I ujarzmiajcie ją. I panujcie } \\
\text { nad rybami morza, i nad ptactwem niebios i nad } \\
\text { wszelkim zwierzęciem pełzającym po ziemi. }{ }^{29} \\
\text { I powiedział Bóg: Oto dałem wam wszelką roślinę } \\
\text { przynoszącą nasienie po powierzchni całej ziemi } \\
\text { i wszelkie drzewo, którego owoc ma w sobie na- } \\
\text { sienie: dla was niech będą pożywieniem. }{ }^{30} \text { A dla } \\
\text { wszelkiego zwierzęcia ziemi, i dla wszelkiego ptac- } \\
\text { twa niebios, i dla wszelkiego pełzającego po ziemi, } \\
\text { w którym jest istota żyjąca, wszelka trawa zielona } \\
\text { będzie pożywieniem. I stało się tak. }{ }^{31} \text { I widział Bóg } \\
\text { wszystko, co uczynił, i oto [było to] bardzo dobre. } \\
\text { I stał się wieczór, i stał się poranek - dzień szósty. }\end{array}$ & \\
\hline
\end{tabular}

33 Zob. J. T. G. A. M. van Ruiten, Primaeval History Interpreted, 41-42. 
Opis stworzenia zwierząt i ludzi w szóstym dniu jest w Jub 2 znacznie krótszy od tego, który znajduje się w Rdz 1,24-31. W obu tekstach zostają wymienione podobne rodzaje zwierząt, które zostały w tym dniu stworzone. W podsumowaniu opisu szóstego dnia autor Jub 2 stwierdza, że Bóg stworzył cztery rodzaje, a są nimi: zwierzęta lądowe/ziemskie (= zwierzęta dzikie), bydło (= zwierzęta domowe), zwierzęta pełzające/poruszające się po ziemi oraz lu$\mathrm{dzie}^{34}$. Podobnie jak w trzecim i piątym dniu, tutaj również autor Jub 2 unika stwierdzenia, aby „ziemia wydała (תוצא הארץ) istotę żyjącą według swego rodzaju” (Rdz 1,24), ale z naciskiem stwierdza, iż to sam Bóg bezpośrednio stworzył istoty żywe na ziemi.

Czwartym i ostatnim dziełem szóstego dnia są ludzie - mężczyzna i kobieta - jako zakończenie stwórczej działalności Boga nie tylko w tym dniu, ale wszystkich pozostałych. Ten wieńczący całe stworzenie charakter powołania do istnienia ludzi został podkreślony przez autora Jub 2 w stwierdzeniu: „A po tym wszystkim uczynił ludzi” (Jub 2,14), czego brak w Rdz 1. Porównując Jub 2,13-14 oraz Rdz 1,26-31 można zauważyć, że w obu tych tekstach wspólny jest tylko sam fakt stworzenia ludzi jako mężczyzny i kobiety oraz danie im przez Boga władzy nad całym światem. Zachował się częściowo tekst hebrajski Jub 2,2: עשה את האדם זכר ונק[בה...uczynił ludzi, mężczyznę i kobie[tę]”. Podobnie jak w Rdz 1,26-27, autor Jub 2 używa terminu אדם, „człowiek; ludzie” w sensie kolektywnym, jak również uwypukla zróżnicowanie płciowe dzięki

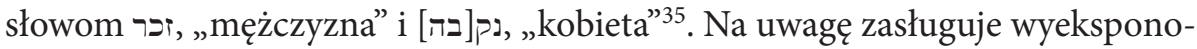
wanie w Jub 2 tego, że Bóg sam stworzył człowieka (tj. עשה, „uczynił”), a więc bez jakiejkolwiek „konsultacji”, na co wydaje się wskazywać tekst w Rdz 1,26: „uczyńmy (נעשה) człowieka”36. Zmiana wprowadzona przez autora Jub 2 ma na

34 Zob. O. S. Wintermute, Jubilees, 57; J.C. VanderKam, Genesis 1 in Jubilees 2, 514.

35 Niektórzy uczeni uważają, że według Jub 2,14 w pierwszym dniu został stworzony jedynie mężczyzna, natomiast kobieta została stworzona dopiero w drugim tygodniu. Ich zdaniem wzmianka o mężczyźnie i kobiecie w Jub 2,14 jest późniejszym dodatkiem, zob. np. M. Testuz, Les idées religieuses du livre des Jubilés, Geneva 1960, 45; J. R. Levison, Portraits of Adam in Early Judaism. From Sirach to 2 Baruch (JSPSup 1), Sheffield 1988, 90-91, 214-215. Taka opinia nie ma jednak żadnego uzasadnienia w tekście Ksieggi Jubileuszów, o czym świadczy zachowany tekst hebrajski Jub 2,14 z Qumran (4Q216 frag. 1, kol. 7, linia 2).

36 Z gramatycznego punktu widzenia liczba mnoga czasownika „uczyńmy” w Rdz 1,26 jest uważana za pluralis deliberationis, a więc Bóg rozważa w sobie, zastanawia się, naradza się sam ze sobą, zob. A. E. Cowley (red.), Gesenius' Hebrew Grammar, Oxford 1910, 398 (\$ 124g); P. Joüon. T. Muraoka, A Grammar of Biblical Hebrew. Part Three: Syntax (SubBi 14/2), t. II, Roma 2003, 375 ( $\$ 114$ e). Wydaje się uzasadniona opinia, że liczba mnoga w Rdz 1,26 jest echem przekonania wspólnego dla mieszkańców starożytnego Bliskiego Wschodu, 
celu uwypuklenie prawdy o Bogu jako jedynym Stwórcy (kolejna! zob. dzień 3 i 5), a jest tym bardziej znacząca, gdy ma się na uwadze fakt stworzenia aniołów w pierwszym dniu, czego brak w $\mathrm{Rdz} 1^{37}$. Poza tymi podobieństwami, autor Jub 2 pomija wiele elementów opisu stworzenia ludzi, który znajduje się w Rdz 1. W Księdze Jubileuszów nie ma wzmianki o Bożym błogosławieństwie dla ludzi, brak rozkazu Boga dotyczącego rozmnażania się, zapełniania ziemi i jej ujarzmiania, nie pojawia się również informacja o pożywieniu. Najbardziej intrygującym jest pominięcie tego, że ludzie zostali stworzeni na obraz i podobieństwo Boga. Należy jednak stanowczo stwierdzić - jak słusznie zauważa J.C. VanderKam ${ }^{38}$ - że całkowicie nieuzasadniona jest opinia jakoby autor Jub 2 odrzucał naukę o podobieństwie człowieka do Boga znajdującą się w Rdz 1,26-27. O jego poglądzie w tym względzie świadczy tekst w Jub 6,8, gdzie prawda ta została wyraźnie wyrażona: „Osoba, która przeleje krew człowieka, (to wtedy) jego krew zostanie przelana przez człowieka, ponieważ On uczynił ludzi na obraz Pana". Trudno jednoznacznie stwierdzić, dlaczego autor Jub 2 pominął to, że człowiek został stworzony na obraz i podobieństwo Boga. Uczeni proponują różne rozwiązania tej kwestii, które jednak nie wydają się w pełni przekonywujące ${ }^{39}$. Najprawdopodobniej autor Jub 2 uznał tę sprawę za tak oczywistą, że ją pominął. Warto zauważyć, że dużo uwagi poświęca on sprawie władzy, jaką Bóg przekazał człowiekowi nad całym światem i wszystki-

zwłaszcza zaś obecnego w mitologii kananejskiej poświadczonej przez literaturę z Ugarit, o istnieniu dworu niebiańskiego, na czele którego stało najwyższe bóstwo otoczone bóstwami niższej rangi. W tradycji biblijnej takie przekonanie zostało odmitologizowane, a miejsce bóstw zajęli aniołowie otaczający tron JHWH w niebiosach. Autor Rdz 1,26 nawiązuje do tego przekonania i czyni aluzję do podejmowania przez Boga decyzji, którą konsultuje z aniołami (zob. Hi 1-2). W późniejszej literaturze żydowskiej często ukazuje się aniołów w roli doradców Boga (np. GenR 8,4; NumR 19,3; EcclR 7,23; Midrasz do Ps 8,3; b.Sanhedrin 38b; Tg. Ps.-J. do Rdz 1,26), zob. F. M. Cross, Canaanite Myth and Hebrew Epic. Essays in the History of the Religion of Israel, Cambridge - London 1997, 186-190; J. T. G. A. M. van Ruiten, Primaeval History Interpreted, 44-45. Szerzej na temat dworu niebiańskiego, zob. E. T. Mullen, Jr., The Divine Council in Canaanite and Early Hebrew Literature (HSM 24), Chico 1980 (o Rdz 1,26 na s. 216).

37 Zob. J. T. G. A. M. van Ruiten, Primaeval History Interpreted, 44.

38 J. C. VanderKam, Genesis 1 in Jubilees 2, 514; zob. też J. T. G. A. M. van Ruiten, Primaeval History Interpreted, 45.

39 K. Berger (Das Buch der Jubiläen, w: JSHRZ II/3, 328) uważa, że podobieństwo do Boga odnosi się tylko do Izraela, stąd autor Jub 2 pomija to zagadnienie w odniesieniu do wszystkich ludzi, natomiast O. H. Steck (Die Aufnahme von Genesis 1 in Jubiläen 2 und 4. Ezra 6, 170-171) jest zdania, że autor Jub 2 koncentruje się przede wszystkim na opisie stwórczej działalności Boga. 
mi istotami żyjącymi, co według Rdz 1 jest jednym z przejawów podobieństwa człowieka do Boga ${ }^{40}$. Innymi słowy, autor Jub 2 chociaż nie mówi o tym wprost, to jednak wyraża prawdę o podobieństwie człowieka do Boga poprzez ukazanie jego funkcji w świecie polegającej na sprawowaniu władzy z ramienia Boga nad całym stworzeniem. Warto zauważyć, że w wielu pismach z okresu Drugiej Świątyni jest mowa o władzy człowieka nad światem, którą otrzymał od Boga, bez wyraźnego podkreślania podobieństwa człowieka do Boga (np. 4 Ezd 6,54; 2 Bar 14,18; 2 Hen 30,8).

Konkluzja (Jub 2,15-16; = 4Q216 frag. 1, kol. 7, linie 4-5). Opis sześciu dni stworzenia kończy się pewnego rodzaju podsumowaniem, w którym stwierdza się, że stwórcza działalność Boga została zakończona.

\begin{tabular}{|l|l|}
\hline \multicolumn{1}{|c|}{ Rdz 2,1 } & \multicolumn{1}{|c|}{ Jub 2,15-16 } \\
\hline $\begin{array}{l}\text { 1 I zostały skończone niebiosa i ziemia } \\
\text { i wszelki ich zastęp. }\end{array}$ & ${ }^{15}$ Razem były dwadzieścia dwa rodzaje. \\
& ${ }^{16}$ I zakończył wszystkie swoje dzieła dnia \\
& szóstego, wszystko, co jest w niebiosach, \\
& na ziemi, w morzach,w otchłaniach, \\
& w świetle, w ciemnościach, i w każdym \\
& miejscu. \\
\hline
\end{tabular}

Podobnie jak w Rdz 2,1, opis sześciu dni stworzenia w Księdze Jubileuszów zawiera podsumowanie (Jub 2,15-16), które stanowi jednocześnie przejście do sekcji poświęconej opisowi ustanowienia szabatu i praw dotyczących jego zachowania (Jub 2,17-33).

Podsumowując wszystkie dzieła stworzenia autor stwierdza, że było ich razem dwadzieścia dwa (Jub 2,16). Tę samą liczbę podaje w Jub 2,23, gdzie zestawia dwadzieścia dwa dzieła stworzone przez Boga $\mathrm{z}$ dwudziestu dwoma przywódcami od Adama do Jakuba: „Było dwudziestu dwóch przywódców ludzkości od Adama aż do niego (tj. Jakuba) i dwadzieścia dwa rodzaje dzieł zostały uczynione do siódmego dnia. Późniejsze jest błogosławione i święte, i wcześniejsze jest błogosławione i święte. To i tamto zostało uczynione dla świętości i błogosławieństwa”. Autor Jub 2 wyraża przekonanie, że 22 dzieła stworzenia są paralelne do 22 przywódców ludzkości od Adama do Jakuba. Dzięki temu zestawieniu został uwypuklony związek istniejący między szabatem a Izraelem. Po dwudziestu dwóch dziełach stworzenia Bóg odpoczął siódmego dnia, który jest błogosławiony i święty (= szabat). Po dwudziestu dwóch

40 Zob. J. C. VanderKam, Genesis 1 in Jubilees 2, 515. 
przywódcach ludzkości pojawia się Jakub, który jest błogosławiony i święty (= Izrael), a jego potomstwo jako jedyny naród wśród całej ludzkości zachowuje szabat. W ten sposób autor Jub 2 wyraża prawdę o związku pomiędzy stworzeniem, szabatem i wybraniem Izraela istniejącym dzięki Bogu, który to wszystko uczynił już na samym „początku”41. Księga Jubileuszów jest najwcześniejszym pismem, w którym pojawia się motyw dwudziestu dwóch dzieł dokonanych przez Boga w ciągu sześciu dni stworzenia. Później ten motyw pojawia się często w tradycji chrześcijańskiej, jak również jest obecny w literaturze żydowskiej, chociaż w różnych źródłach podaje się inną liczbę dzieł. W Midraszu do Księgi Rodzaju jest mowa o osiemnastu oraz dwudziestu jeden dziełach (GenR 11,9). W średniowiecznym Midraszu Tadshe wykazującym wiele zbieżności z Księga Jubileuszów jest mowa o dwudziestu dwóch dziełach, ale chociaż ogólna liczba zgadza się z Jub 2, to jednak zachodzą różnice w szczegółach (rozdz. 6) ${ }^{42}$. Podobnie jak w Jub 2, liczbę dzieł stworzonych (tj. 22) zestawia się z liczbą dwudziestu dwóch przywódców od Adama do Jakuba, jak również dodaje się liczbę dwudziestu dwóch liter w alfabecie hebrajskim ${ }^{43}$.

W Jub 2,16 autor stwierdza, że Bóg „zakończył wszystkie swoje dzieła” oraz wylicza siedem miejsc Jego stwórczej działalności, a mianowicie niebiosa, ziemię, morza, otchłanie, światło, ciemność, każde miejsce. Warto zauważyć, że liczba siedem jest szczególnie eksponowana $\mathrm{w}$ opisie stworzenia znajdującym się w Jub 2: siedem dni całego opisu ( 6 dni pracy +1 dzień odpoczynku), siedem dzieł dokonanych przez Boga w pierwszym dniu, siedem kategorii duchów / aniołów, wreszcie siedem kategorii istot żyjących stworzonych razem w piątym (3 rodzaje) i szóstym dniu (4 rodzaje) ${ }^{44}$.

41 Zob. O. H. Steck, Die Aufnahme von Genesis 1 in Jubiläen 2 und 4. Ezra 6, 160-162; J. C. VanderKam, Genesis 1 in Jubilees 2, 518; L. Fusella, Libro dei Giubilei, 129-130.

42 Zob. A. Epstein, Le livre des Jubiles, Philon et le midrasch Tadsche, 83-85; J. C. VanderKam, Genesis 1 in Jubilees 2, 516-517.

43 Zob. A. Wünsche, Midrash Tadsche oder Baraitha des R. Pinchas ben Jair, w: A. Wünsche, Aus Israels Lehrhallen, t. V, Hildesheim 1967, 97. R. H. Charles (The Book of Jubilees or the Little Genesis, 17-18) powołując się na świadectwo Epifaniusza i innych pisarzy czerpiących z Księgi Jubileuszów uważał, że w tekście etiopskim w Jub 2,23 oryginalnie oprócz 22 dzieł stworzenia i 22 przywódców była również mowa o 22 literach alfabetu hebrajskiego i 22 księgach Biblii Hebrajskiej. Dlatego, uzupełniając tekst, dodaje on wzmiankę o literach i księgach, zob. też O. H. Steck, Die Aufnahme von Genesis 1 in Jubiläen 2 und 4. Ezra 6, 165. Jednakże taka rekonstrukcja wydaje się nieuzasadniona, co przede wszystkim potwierdza fragmentarycznie zachowany tekst hebrajski z Qumran (4Q216 frag. 1, kol. 7, linie 14-16), gdzie nie ma miejsca na takie uzupełnienie, zob. J. C. VanderKam, The Book of Jubilees, t. II, 13-14.

44 Zob. J. C. VanderKam, Genesis 1 in Jubilees 2, 515; J. T. G. A. M. van Ruiten, Primaeval History Interpreted, 51. 
DZIEŃ SIÓDMY - SZABAT (Jub 2,17-33). Tekst hebrajski z Qumran odnoszący się do szabatu zachował się w stanie szczątkowym, mianowicie 4Q216 frag. 1, kol. 7, linia 17 (= Jub 2,17) oraz 4Q218 frag. 1, linie 1-4 (= Jub 2,26-27).

W Rdz 2,2-4a o siódmym dniu jest mowa w bardzo zwięzły sposób: ” I skończył Bóg w dniu siódmym swoje dzieło, które uczynił. I odpoczął w dniu siódmym od całego swego dzieła, które uczynił. ${ }^{3}$ I pobłogosławił Bóg dzień siódmy i uświęcił go, bo w nim odpoczął od całego swego dzieła, które stworzył Bóg, gdy działał. ${ }^{4}$ Takie są dzieje początków niebios i ziemi”. Warto zauważyć, że nie ma tu wyraźnie mowy o ustanowieniu siódmego dnia czasem odpoczynku, a jedynie stwierdza się, że w tym dniu Bóg odpoczął. Autor wymienia tu trzy czynności Boga odnoszące się do siódmego dnia, a mianowicie „odpoczął”, „pobłogosławił” i „uświęcił”. Obowiązek zachowania szabatu przez ludzi - na wzór Boga - jest więc niejako zakładany przez autora Rdz 1-2,4a.

W Księdze Jubileuszów sekcja poświęcona szabatowi jest bardzo obszerna (Jub 2,17-33) i można w niej wyodrębnić dwie zasadnicze części, mianowicie opis ustanowienia szabatu $(2,17-24)$ oraz przepisy dotyczące jego przestrzegania (2,25-33). Podobnie jak w opisie sześciu dni stworzenia (Jub 2,2-16), narratorem jest anioł obecności przekazujący Mojżeszowi słowa objawienia dane przez Boga. W bardzo wyraźny sposób autor Jub 2 stwierdza, że szabat został stworzony przez Boga: „I uczynił wielki znak, dzień szabatu, abyśmy mogli pracować przez sześć dni i zachowywać szabat, powstrzymując się od pracy w siódmym dniu" (Jub 2,17; zob. też 2,21.25). Według Jub 2, obowiązek zachowania szabatu odnosi się do aniołów. W Jub 2,18 autor stwierdza, że Bóg zachowuje szabat razem $\mathrm{z}$ aniołami: „Powiedział do nas - wszystkich aniołów obecności i wszystkich aniołów świętości, dwóch największych grup - abyśmy zachowywali szabat razem z nim w niebiosach i na ziemi" (zob. też Jub 2,21.30). Warto zwrócić uwagę na fakt, że według Jub 2 szabat zachowują jedynie dwie kategorie aniołów, mianowicie aniołowie obecności i aniołowie świętości. Pozostałe pięć kategorii aniołów reprezentuje zjawiska naturalne (zob. Jub 2,2), które najprawdopodobniej w opinii autora posiadają niższy status $\mathrm{w}$ hierarchii istot niebiańskich. Można przypuszczać, że autor Jub 2 czyni wśród istot niebiańskich rozróżnienie podobne do tego, które istnieje wśród ludzi, na co może wskazywać wzmianka o zachowaniu szabatu „W niebiosach i na ziemi” (Jub 2,18). W takim razie zachowywanie szabatu staje się kryterium podziału zarówno wśród aniołów, jak i wśród ludzi. Naród Izraela dzięki szabatowi przewyższa wszystkie inne narody (Jub 2,19), podobnie przestrzeganie szabatu wyróżnia aniołów obecności i aniołów świętości od wszystkich pozostałych ${ }^{45}$.

45 Zob. L. Fusella, Libro dei Giubilei, 128-129; zob. D. S. Russell, The Method and Message of Jewish Apocalyptic, 200 BC - AD 100 (The Old Testament Library), Philadelphia 1964, 241. 
W kontekście opisu ustanowienia szabatu autor Jub 2 ukazuje szczególną relację i więź istniejącą pomiędzy Bogiem i Izraelem oraz jego wyjątkową pozycję wśród innych narodów. W Jub 2,19-20 Bóg wypowiada następujące słowa: „Ja oddzielę dla siebie jeden lud spośród wszystkich narodów [...] Ja uświęcę ich dla siebie [...] oni będą moim ludem, a Ja będę ich Bogiem [...] Ja wybrałem potomstwo Jakuba spośród tych wszystkich, których widziałem. Ja ustanowiłem ich jako mego pierworodnego syna i uświęciłem ich dla siebie na wieki wieczności [...]”. W Jub 2,21 anioł narrator kontynuuje: „pobłogosławił ich i uświęcił ich dla siebie jako wybitny lud wśród wszystkich narodów". Najważniejszym kryterium uprzywilejowanej pozycji Izraela wśród wszystkich narodów świata jest zachowywanie szabatu. W Jub 2,31 autor z naciskiem podkreśla, że „Stwórca wszystkiego pobłogosławił ${ }^{46}$, ale nie uświęcił żadnego ludu ani narodu dla zachowywania szabatu, z wyjątkiem tylko Izraela”. Myśl tej wypowiedzi jest taka, że Bóg pobłogosławił wszystkie ludy i narody, ale tylko lud Izraela obdarzył przywilejem zachowywania szabatu, co równocześnie jest powodem jego uświęcenia (zob. Jub 2,23). Innymi słowy, Izrael został wybrany dla zachowywania szabatu, a zachowywanie szabatu będzie znakiem, że Bóg uświęcił Izraela ${ }^{47}$.

W Jub 26-30 autor opisuje prawa dotyczące zachowania szabatu, zaś karą za jego znieważenie jest śmierć. Jednakże większy nacisk został położony na świętość, błogosławieństwo i uroczysty charakter dnia szabatu, który zachowuje sam Bóg, dwie główne grupy aniołów i Izrael. W ten sposób dla autora Jub 2 trzy rzeczy, mianowicie stworzenie, szabat i wybranie Izraela, należą do tego samego porządku, który został ustanowiony przez Boga od samego „początku"48.

46 Większość uczonych dodaje w tym miejscu zaimek i czyta „pobłogosławił go”, tj. szabat (np. R. H. Charles, O.S. Wintermute, A. Kondracki). Tymczasem suffix zaimka rodzaju męskiego pojawia się jedynie w dwóch rękopisach, w późniejszych kopiach występuje suffix zaimka rodzaju żeńskiego, natomiast w najlepszych manuskryptach brak jakiegokolwiek zaimka, zob. J. C. VanderKam, The Book of Jubilees, t. II, 15.

47 Zob. J. T. G. A. M. van Ruiten, Primaeval History Interpreted, 49; J. C. VanderKam, The Book of Jubilees, t. II, 15; tenże, The Book of Jubilees (Guides to Guides to Apocrypha and Pseudepigrapha), 29-30; G. Boccaccini, Middle Judaism: Jewish Thought, 300 B.C.E. to 200 C.E., Minneapolis 1991, 259-262.

48 Zob. J. C. VanderKam, Genesis 1 in Jubilees 2, 318; tenże, The Book of Jubilees Guides to Apocrypha and Pseudepigrapha), 30; J. T. G. A. M. van Ruiten, Primaeval History Interpreted, 49; L. Doering, The Concept of the Sabbath in the Book of Jubilees, w: M. Albani i in. (red.), Studies in the Book of Jubilees (TSAJ 65), Tübingen 1997, 185-188. 


\section{Podsumowanie}

Opis stworzenia świata znajdujący się w Księdze Jubileuszów (Jub 2) wzoruje się na heksaemeronie z Rdz 1,1-2,4a i stanowi jego interpretację mającą na celu wyeksponowanie kilku tematów, które są ważne dla autora Jub 2. Są nimi: stworzenie, szabat i wybranie Izraela. W obu kompozycjach ogólna struktura jest taka sama, a więc podział materiału według schematu sześciu dni stwórczej działalności Boga i siódmego dnia Jego odpoczynku. Jednakże w Jub 2 cały opis jest poprzedzony wstępem, gdzie jest mowa o tym, że relację o stworzeniu przekazuje Mojżeszowi na górze Synaj anioł w imieniu Boga (Jub 2,1), zaś sekcja poświęcona szabatowi jest znacznie dłuższa i zawiera o wiele więcej szczegółów niż w Rdz 2,2-3 (Jub 2,17-33). Autor Jub 2 włącza również materiał z Rdz 2, czego przykładem jest wzmianka o ogrodzie Eden $(2,7)$ oraz nazywanie Boga „Panem” (np. 2,7.9.25). Obok licznych podobieństw i różnic, w Jub 2 pojawiają się dwa motywy zasługujące na szczególną uwagę, a których brak w Rdz 1,1-2,4a, mianowicie stworzenie aniołów w pierwszym dniu (Jub 2,2) i ogrodu Eden w trzecim dniu (Jub 2,7).

Ze szczególnym naciskiem autor Jub 2 wyraża prawdę o Bogu jako jedynym Stwórcy wszystkiego, co wyrażają zawsze bezpośrednio do Niego odnoszone czasowniki, m.in. „stworzył”, „uczynił”, ustanowił”. W celu uniknięcia wszelkich dwuznaczności, autor Jub 2 unika wzmianek o tym, że ziemia wydaje rośliny (por. $R d z 1,12$ ), wody istoty pływające (por. $\operatorname{Rdz} 1,20$ ), a ziemia istoty żyjące na niej (por. Rdz 1,24). Zwieńczeniem całego dzieła stworzenia jest powołanie do istnienia człowieka - mężczyzny i kobiety. Według autora Jub 2 Bóg nie zasięga „rady” aniołów w sprawie stworzenia człowieka (por. Rdz $1,26)$, chociaż zostali oni stworzeni już w pierwszym dniu. Ich funkcją jest błogosławienie i wychwalanie Boga za wspaniałe dzieło stworzenia, jak również zachowywanie razem z Nim szabatu.

Autor Jub 2 z niezwykłą emfazą uwypukla rolę i znaczenie słońca, od którego zależą wszystkie ustalenia kalendarzowe. Dominująca pozycja słońca została wyeksponowana poprzez całkowite odrzucenie księżyca w wyznaczaniu czasu. Tylko słońce - razem z szabatem - zostało nazwane „wielkim znakiem” (Jub 2,9).

Całe opowiadanie o stworzeniu w Jub 2 służy wyeksponowaniu dwóch tematów, mianowicie szabatu i wybrania Izraela. Poprzez połącznie ich z dziełem stworzenia autor Jub 2 wyraża myśl, że zostały ustanowione przez Boga już od samego „początku”. Pomiędzy nimi istnieje łączność, którą autor wyraża za pomocą symboliki liczb: po dokonaniu 22 dzieł w czasie sześciu dni stworzenia Bóg odpoczął w dniu szabatu, zaś po 22 przywódcach nastał Jakub i jego po- 
tomstwo, które zachowuje szabat. Błogosławiony i święty jest zarówno szabat, jak i Izrael. Bóg wybrał Izraela spośród wszystkich narodów, aby ten zachowywał szabat, a dzięki temu, że Izrael zachowuje szabat, Bóg go uświęca i zapewnia mu swoje błogosławieństwo. Ksiega Jubileuszów jest świadectwem bardzo radykalnego przekonania charakterystycznego dla okresu Drugiej Świątyni, że zachowywanie szabatu jest podstawowym czynnikiem określającym tożsamość Izraela w relacji do Boga oraz powodem wybrania Izraela, czego rezultatem jest jego wyjątkowy status wśród wszystkich narodów (zob. Jub 2,21.31).

\section{Summary}

The Book of Jubilees was written in Hebrew around the middle of the second century B.C. This document has taken from the biblical creation story (Gen 1,1-2,4a) the arrangement into six days of work, after which comes the seventh day of rest. Like Genesis, Jubilees numbers the days and details what was made on each one. There are, however, some differences. For example, the creation of the angels on the first day (Jub 2,2 ) and the mention of the Garden of Eden (Jub 2,7). The Book of Jubilees highlights many of the themes. Firstly, the emphasis in Jubilees lies on God as creator and recipient of praise. God alone created the universe and all its parts. Secondly, the sun is ruler of times in the creation. The sun alone has calendrical duties, not the moon and stars. The sun, like the sabbath, is a great sign given by God. Thirdly, Israel's election is built into creation story, as God rested at the end of 22 works, so Jacob (Israel) arose after 22 generations. Jacob (Israel) and the sabbath are blessed and holy. Israel was chosen to keep the sabbath. 